\title{
Primary extramedullary malignant plasmacytoma mimicking carcinoma of rectum
}

\author{
Tadashi Terada * \\ Department of Pathology, Shizuoka City Shimizu Hospital, Shizuoka, Japan
}

Received: December 30, 2015

Accepted: March 13, 2016

Online Published: April 12, 2016

DOI: $10.5430 /$ crcp.v3n4p6

URL: http://dx.doi.org/10.5430/crcp.v3n4p6

\begin{abstract}
The author reports a rare case of extramedullary plasmacytoma (EP) of rectum. A 74-year-old man presented melena. Endoscopy revealed a polypoid tumor in rectum. Biopsy revealed poorly cohesive malignant cells resembling plasma cells. The biopsy was erroneously diagnosed by author as poorly differentiated adenocarcinoma. Resection of rectum was performed. Gross examination showed a polypoid tumor measuring $6 \mathrm{~cm} \times 5 \mathrm{~cm} \times 5 \mathrm{~cm}$. Microscopically, the tumor was composed of poorly cohesive malignant cells resembling plasma cells. Three lymph nodes out of 29 lymph nodes dissected revealed similar malignant cells. Differential diagnosis was needed among plasmacytoid adenocarcinoma, signet-ring cell carcinoma, malignant lymphoma, EP, and poorly differentiated adenocarcinoma. Immunohistochemically, the tumor cells showed positive reaction for vimentin, p53, Ki-67 (labeling = 43\%), CD45, CD20, CD38, CD138, CD79 $\alpha$, CD3, CD45RO, CD56, $\kappa$-chain and $\lambda$-chain. The tumor cells were negative for CK AE1/3, CK CAM5.2, CK WSS, CK34BE12, CK5/6, CK7, CK8, CK14, CK18, CK19, CK20, EMA, p63, CEA, CA19-9, CDX-2, NSE, synaptophysin, chromogranin, MUC1, MUC2, MUC5AC, and MUC6. The final pathological diagnosis was primary extra-medullary malignant plasmacytoma of rectum. Imaging techniques showed no other tumors in the body. The bones were normal, excluding multiple myeloma. The blood leukocytes and their segments were normal. The patient was treated by chemotherapy, and the disease cured. He died of other cause (pneumonia) five years after the operation.
\end{abstract}

Key Words: Rectum, Plasmacytoma, Polyclonal, Histopathology, Immunohisochemistry

\section{INTRODUCTION}

Extramedullary (extra-osseous) plasmacytoma (EP) is a potentially malignant neoplasm composed of neoplastic plasma cells. ${ }^{[1]}$ EP can develop in any organs. ${ }^{[1]}$ Monoclonal malignant plasma cell neoplasms of bones are termed as multiple myeloma or plasma cell myeloma. ${ }^{[2]} \mathrm{EP}$ in colorectum is rare. ${ }^{[3-12]}$

Carcinoma cells can resemble plasma cells, and such cases are called plasmacytoid carcinoma (PC). In particular, PC has been described among urothelial carcinomas. These plasmacytoid urothelial carcinomas do not show CD38, CD138 (the plasma cell antigens) and CD79 $\alpha$ (a possible plasma cell marker). Recently, the author reported PC in lung ${ }^{[13]}$ and stomach. ${ }^{[14]}$ These PC of several organs are difficult to differentiate from EP. EP and PC are not described in WHO blue book of digestive organs, although there is a section of B-cell lymphoma in the blue book.

\section{CASE REPORT}

A 74-year-old man presented with constipation and melena. Blood laboratory test showed anemia. The white blood cells and their segment were within normal ranges. Serum pro-

\footnotetext{
*Correspondence: Tadashi Terada; Email: piyo0111jp@yahoo.co.jp; Address: Department of Pathology, Shizuoka City Shimizu Hospital, Miyakami 1231 Shimizu-Ku, Shizuoka 424-8636, Japan.
} 
teins were within normal limits. No proteinuria was found. No $\mathrm{M}$ protein was seen in blood and urine. Colorectal endoscopy revealed a polypoid tumor measuring $6 \mathrm{~cm} \times$ $6 \mathrm{~cm} \times 5 \mathrm{~cm}$ in rectum. Biopsy revealed poorly cohesive malignant cells resembling plasma cells (see Figure 1). Immunohistochemically, tumor cells were positive for vimentin, but negative for cytokeratin (CK) AE 1/3 and CK CAM5.2, suggesting mesenchymal nature. However, the biopsy was erroneously diagnosed by the author as poorly differentiated adenocarcinoma, although the author considered EP, malignant lymphoma, signet-ring cell carcinoma, and PC. Resection of rectum and lymph nodes dissection were performed. Gross examination showed a polypoid type tumor measuring $6 \mathrm{~cm} \times 5 \mathrm{~cm} \times 5 \mathrm{~cm}$ in rectum (see Figure 2). Histologically, the tumor was composed of poorly cohesive malignant cells resembling plasma cells (see Figure 3). The tumor cells were infiltrative, and they were seen in all layers of the rectal walls. Three lymph nodes out of 29 lymph nodes revealed similar malignant cells. The author considered EP, signet-ring cell carcinoma, PC, malignant lymphoma, and poorly differentiated adenocarcinoma, but no definite diagnosis was obtained.

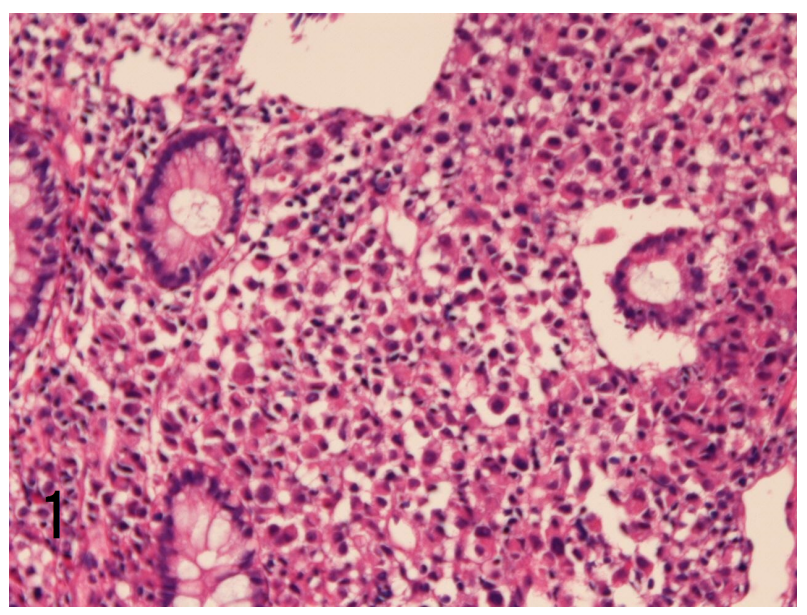

Figure 1. Biopsy histology of rectal tumor

The tumor cells show malignant features such as hypercellularity, nuclear atypia, and nuclear hyperchromasia. The nuclei are eccentrically located, thus resembling plasma cells. $H E, \times 200$.

Therefore, several mucin stains (such as diastase Periodic acid-Schiff/Alcian blue (d-PAS/AB) and d-PAS mucicarmine) and extensive immunohisochemical study was retrospectively done in the biopsy, resected rectal tumor, and lymph node. Various histochemical stains revealed no mucins.

Immunohistochemical investigation was performed by Envision method, as previously reported ${ }^{[15,16]}$ in the following three samples; i.e. rectal biopsy, rectal surgical specimens, and lymph node surgical specimens. The results were the Published by Sciedu Press same among the 3 samples. Immunohistochemically, the tumor cells of these three specimens were positive for vimentin (see Figure 4A), p53, Ki-67 (labeling = 43\%), CD38 (see Figure 4B), CD138 (see Figure 4C), CD45, CD20, CD79 $\alpha$ (see Figure 4D), CD3, CD45RO, CD56, $\kappa$-chain, and $\lambda$-chain. No light chain restriction was seen. The tumor cells were negative for CK AE1/3, CK CAM5.2, CK WSS, CK34BE12, CK5/6, CK7, CK8, CK14, CK18, CK19, CK20, EMA, p63, CEA, CA19-9, CDX-2, NSE, synaptophysin, chromogranin, MUC1, MUC2, MUC5AC, and MUC6. The final pathological diagnosis made by the author was primary polyclonal malignant EP. The patient was treated by chemotherapy, and the disease cured. He died of other cause (pneumonia) five years after the operation at the age of 79 years.

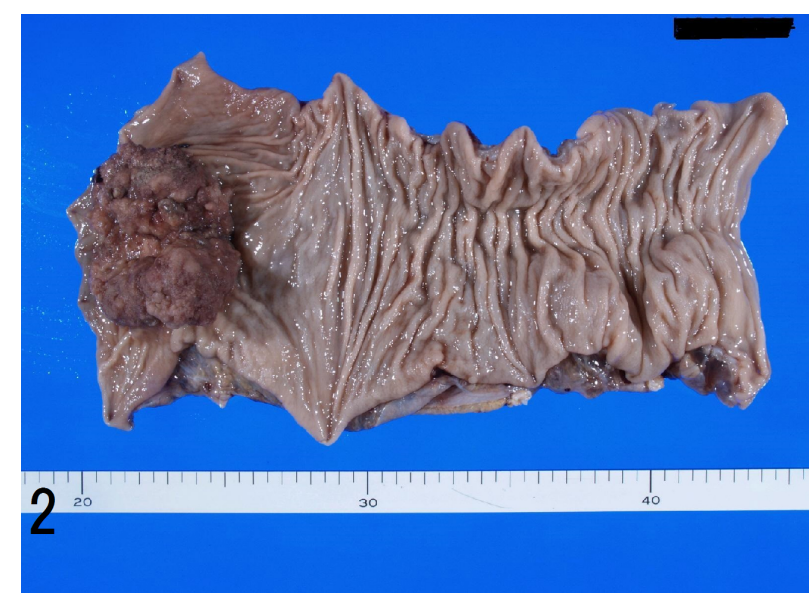

Figure 2. Gross findings of the tumor Gross pathological examination shows a polypoid tumor measuring $6 \mathrm{~cm} \times 5 \mathrm{~cm} \times 5 \mathrm{~cm}($ far left $)$

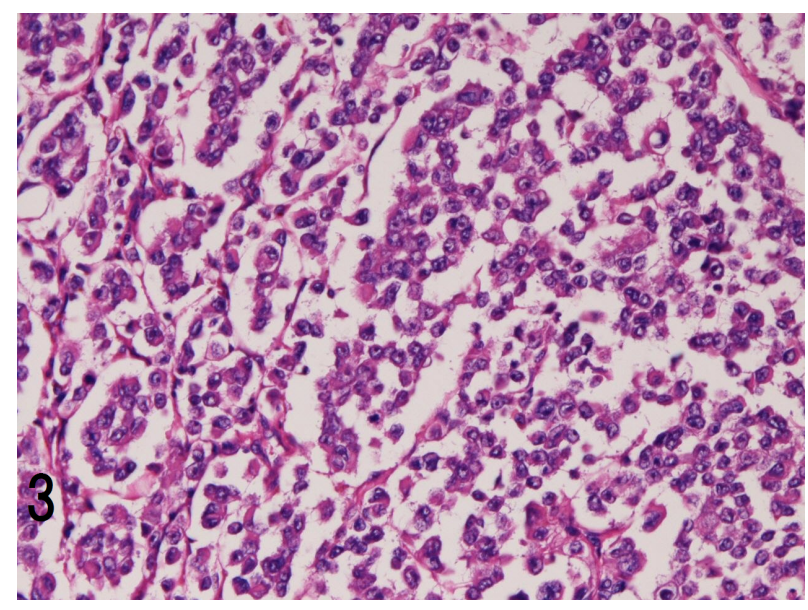

Figure 3. Histologic features of the tumor of the resected rectum

The tumor cells show malignant features such as hypercellularity, nuclear atypia, and nuclear hyperchromasia. The nuclei are eccentrically located, and the tumor cells resemble plasma cells. $H E, \times 200$. 

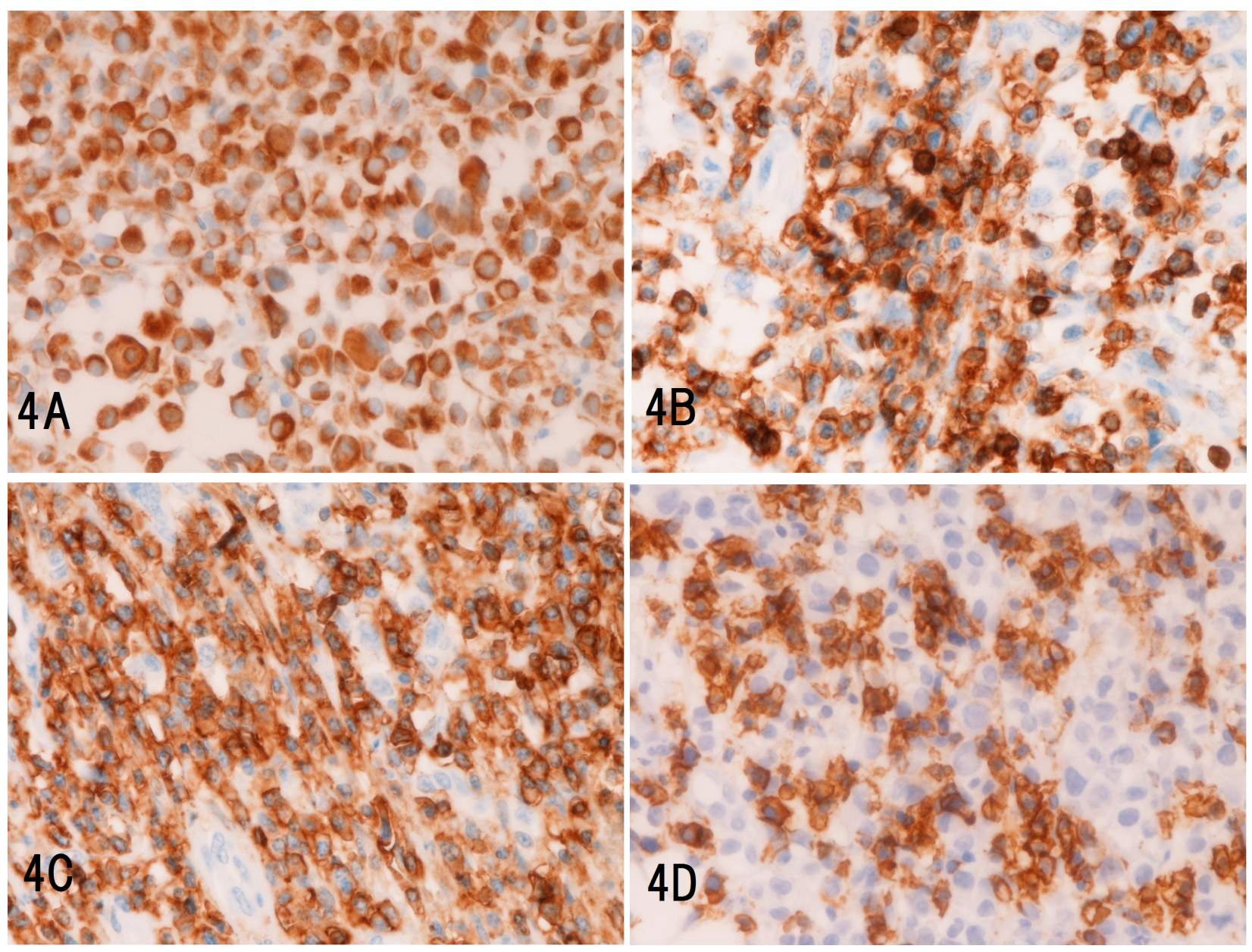

Figure 4. Immunohistochemical findings: Many of tumor cells but not all are positive for vimentin (A), CD38 (B), CD138 (C), and CD79 $\alpha$ (D). Immunostaining, $\times 200$.

\section{DiscuSSION}

The present case was difficult to diagnose. Differential diagnoses include hematopoietic malignancies (EP and malignant lymphoma) and carcinoma (PC, signet-ring cell carcinoma, and poorly differentiated adenocarcinoma). The author finally diagnosed this case as EP.

The positive immunoreactive p53 suggests p53 gene mutations and malignant potential of the current tumor. The high Ki-67 labeling (43\%) indicates a high cell proliferative activity and malignant potential of the present tumor. The $\mathrm{H} \& \mathrm{E}$ histology shows cellular atypia and tumor cell invasion, almost indicating a malignancy of the current tumor. The presence of tumor cells in the three lymph nodes also suggests that the current tumor is malignant. All the data certainly conclude that the current tumor is malignant.

The combined d-PAS/AB and d-PAS stainings suggest the presence of neutral mucins in the tumor cells, though positivity of d-PAS can show residual glycogens after diastase predigestion. The $\mathrm{AB}$ at $\mathrm{pH} 2.5$ staining suggests no acidic mucin in tumor cells. The mucicarmine staining suggests no mucins in the tumor cells. Immunohistochemically, the positive vimentin suggests that the current tumor is mesenchymal tumor. ${ }^{[17]}$ However, this suggestion is not complete because it is well known that carcinoma can express vimentin. The absence of wide ranges of CKs and negative EMA and p63 also suggest that the current tumor is not carcinoma but a non-epithelial tumor. ${ }^{[18]}$ However, this suggestion is not complete because there are a few carcinomas negative for various CKs. The negative reaction for p63, CEA, CA199, CDX-2, NSE, synaptophysin, chromogranin, MUC1, MUC2, MUC5AC, and MUC6 also suggests that the tumor is non-epithelial malignancy. ${ }^{[19]}$ The negative CEA, CA19-9, CDX-2, MUC apomucins (MUC1, MUC2, MUC5AC, MUC6) suggest that the current tumor is not adenocarcinoma. ${ }^{[19]}$ The negative reaction of NSE, chromogranin, and synaptophysin suggests negative neuroendocrine features of the present case. ${ }^{[20]}$ Thus, the negative reaction of various epithelial antigens and positive reaction of vimentin strongly suggest or definitely indicate that the current case 
is not epithelial malignancy. Therefore, it can be concluded that the current tumor is not plasmacytoid adenocarcinoma, signet ring cell carcinoma, and poorly differentiated adenocarcinoma. The only weak point of this statement is the presence of magenta products in the combined d-PAS/AB and d-PAS mucin stainings. This suggests the presence of neutral mucins in tumor cells and also suggests adenocarcinoma. However, it may be probable that the magenta products in these stainings may be glycogen, as is occasional case in these staining. This is strengthened by the fact that the mucicarmine staining showed no products. Therefore, the magenta products do not always indicate that the current tumor is carcinoma, particularly signet ring cell carcinoma.

The remaining differential diagnoses are EP and malignant lymphoma. The positive reaction of vimentin, CD38, CD138, CD45, CD20, CD79 $\alpha, \mathrm{CD} 3, \mathrm{CD} 45 \mathrm{RO}, \mathrm{CD} 56, \kappa$-chain, and $\lambda$-chain strongly suggests that the current tumor is a hematopoietic malignancy. ${ }^{[21]}$ It is well known that CD45 is an antigen of a wide range of leukocytes, CD38, CD138, CD56, CD79 $\alpha, \kappa$-chain and $\lambda$-chain of plasma cells, ${ }^{[1,2]}$
CD20 and CD79 $\alpha$ of B-cell, CD3 and CD45RO of T-cells, and CD56 of NK-cells. The positive reaction of CD38, CD138, CD56, CD79 $\alpha, \kappa$-chain and $\lambda$-chain strongly suggests that the current tumor is a plasma cell malignancy. ${ }^{[1,2]}$ Malignant lymphoma is unlikely because the tumor cells expressed various markers of plasma cells, B-cells, T-cells, and NK-cells. Both $\kappa$-chain and $\lambda$-chain were positive in the tumor cells; thus no light chain restriction was noted, suggesting the polyclonal nature of B-lymphocytes and plasma cells. The author though that the current tumor is EP with polyclonal nature. The polyclonal characteristics are enigma in the present time.

In summary, the author presented a rare case of primary EP of the rectum. Because of its rarity, the biopsy was erroneously diagnosed as adenocarcinoma. An extensive immunohistochemical study was performed, which led to the correct diagnosis. The tumor showed polyclonal character in terms of light chain expressions, the polyclonality remaining an enigma.

\section{REFERENCES}

[1] McKenna RW, Kyle RA, Kuehl WM, et al. Extraosseous plasmacytoma. In: Swerdlow SH, Campo E, Harris NL, Jaffe ES, Pileri SA, Stein H, Thiele J, Vardiman JW. WHO Classification of tumours of haematopietic and lymphoid tissues. Lyon: IARC; 2008. 208p.

[2] McKenna RW, Kyle RA, Kuehl WM, et al. Plasma cell myeloma. In: Swerdlow SH, Campo E, Harris NL, Jaffe ES, Pileri SA, Stein H, Thiele J, Vardiman JW. WHO Classification of tumours of haematopietic and lymphoid tissues. Lyon: IARC; 2008. 202p. PMid: 18562211

[3] Makis W, Ciarallo A, Hickeson M, et al. Gastric recurrence of a primary colon plasmacytoma: staging and evaluating response to therapy with 18F-FDG PET/CT. Br J Radiol. 2012; 85(1009): 4-9. PMid: 22190759. http://dx.doi.org/10.1259/bjr/37953406

[4] Kodani T, Osada T, Terai T, et al. Successful endoscopic mucosal resection of a solitary extramedullary plasmacytoma in the sigmoid colon. Endoscopy. 2011; 43 Suppl 2 UCTN: 298-9.

[5] Kakati BR, Krishna K, Krishna SG, et al. Extensive extramedullary disease involving the colon in multiple myeloma: a case report and review of literature. J Gastrointest Cancer. 2012; 43: 379-81. PMid: 20703830. http://dx.doi.org/10.1007/s12029-010 $-9199-z$

[6] Pacheco DC, de Solórzano MM, Lázaro EQ, et al. Extramedullary plasmacytoma of the colon: a rare cause of gastrointestinal bleeding. Endoscopy. 2009; 41 Suppl 2: E306-7. PMid: 19921603. http://dx.doi.org/10.1055/s-0029-1215225

[7] Islam SR, Attaya MN, Parupudi S, et al. Sigmoid plasmacytoma mimicking colon cancer in a patient with multiple myeloma: case report and review of literature. Gastrointest Endosc. 2010; 71: 6557. PMid: 19879569. http://dx.doi.org/10.1016/j.gie. 200 9.08 .003

Published by Sciedu Press
[8] Suvannasankha A, Abonour R, Cummings OW, et al. Gastrointestinal plasmacytoma presenting as gastrointestinal bleeding. Clin Lymphoma Myeloma. 2008; 8: 309-11. PMid: 18854287. http: //dx.doi.org/10.3816/CLM. 2008.n.044

[9] Jones JE, Brand MI, Saclarides TJ, et al. Primary extramedullary plasmacytomas of the colon. Am Surg. 2008; 74: 873-4. PMid: 18807681.

[10] Doki T, Takeuchi O, Kaiho T, et al. Primary isolated extramedullary plasmacytoma of the colon. Int J Colorectal Dis. 2008; 23: 71920. PMid: 18239923. http://dx.doi.org/10.1007/s00384-0 08-0439-7

[11] Han YJ, Park SJ, Park MI, et al. Solitary extramedullary plasmacytoma in the gastrointestinal tract: report of two cases and review of literature. Korean J Gastroenterol. 2014; 63: 316-20. PMid: 24870305. http://dx.doi.org/10.4166/kjg.2014.63.5.316

[12] Zihni İ, Dinç R, Canpolat S, et al. Extramedullary plasmacytoma of the colon: a case report. Ulus Cerrahi Derg. 2013; 30: 231-3. PMid: 25931923.

[13] Terada T. Plasmacytoid adenocarcinoma of the lung. Int J Clin Exp Pathol. 2012; 5: 356-8. PMid: 22670180.

[14] Terada T. Primary CD138-positive poorly cohesive adenocarcinoma of the stomach whose carcinoma cells resemble plasma cells (plasmacytoid adenocarcinoma of the stomach). J Gastrointest Cancer. 2012; 43 Suppl 1: S208-10. PMid: 22392087. http://dx.doi.org/10. $1007 /$ s12029-012-9375-4

[15] Terada T, Kawaguchi M. Primary clear cell adenocarcinoma of the peritoneum. Tohoku J Exp Med. 2005; 206: 271-5. PMid: 15942157 http://dx.doi.org/10.1620/tjem.206.271

[16] Terada T, Kawaguchi M, Furukawa K, et al. Minute mixed ductalendocrine carcinoma of the pancreas with predominant intraductal growth. Pathol Int. 2002; 52: 740-6. PMid: 12685552. http: //dx.doi.org/10.1046/j.1440-1827.2002.01416.x 
[17] Polioudaki H, Agelaki S, Chiotaki R, et al. Variable expression levels of keratin and vimentin reveal differential EMT status of circulating tumor cells and correlation with clinical characteristics and outcome of patients with metastatic breast cancer. BMC Cancer. 2015; 15 : 399. http://dx.doi.org/10.1186/s12885-015-1386-7

[18] Terada T, Hoso M, Nakanuma Y. Distribution of cytokeratin 19positive biliary cells in cirrhotic nodules, hepatic borderline nodules (atypical adenomatous hyperplasia), and small hepatocellular carcinomas. Mod Pathol. 1995; 8: 371-9. PMid: 7567933.

[19] Terada T, Ohta T, Sasaki M, et al. Expression of MUC apomucins in normal pancreas and pancreatic tumours. J Pathol. 1996;
180: 160-5. http://dx.doi.org/10.1002/(SICI) 1096-989 6(199610) $180: 2<160:$ :AID-PATH625>3.0.CO; 2 -A

[20] Terada T. Ontogenic development of nerve fibers in human fetal livers: an immunohistochemical study using neural cell adhesion molecule (NCAM) and neuron-specific enolase (NSE). Histochem Cell Biol. 2015; 143: 421-9. PMid: 25326085. http: //dx.doi.org/10.1007/s00418-014-1286-y

[21] Terada T. Gastrointestinal malignant lymphoma: a pathologic study of 37 cases in a single Japanese institution. Am J Blood Res. 2012; 2: 194-200. PMid: 23119230. 